\title{
Cloning and Deletion Analysis of a Genomic Segment of Bacillus subtilis Coding for the $s d h A, B, C$ (Succinate Dehydrogenase) and gerE (Spore Germination) Loci
}

\author{
By SHAHIDA HASNAIN, RACHEL SAMMONS, IAN ROBERTS $\uparrow$ AND \\ CHRISTOPHER M. THOMAS* \\ Department of Genetics, University of Birmingham, PO Box 363, Birmingham B15 2TT, UK
}

(Received 22 March 1985; revised 3 May 1985)

From a Bacillus subtilis gene bank constructed in Escherichia coli and based on a low copy number cloning vector we have isolated a hybrid plasmid, pSH1047, containing an $8.0 \mathrm{~kb}$ segment of $B$. subtilis DNA coding for the $s d h A, B$ and $C$ genes, which code for the component polypeptides of succinate dehydrogenase, and the gerE gene, which may code for or regulate a protease involved in producing spores which germinate normally. We report the restriction map of this segment and the analysis of deletion derivatives which allow us to correlate the physical and genetic maps of these chromosomal segments.

\section{INTRODUCTION}

Bacillus subtilis is a Gram-positive bacterium whose natural habitat is the soil. Biochemical and genetical analyses of $B$. subtilis have been facilitated by its convenient growth characteristics and because certain laboratory strains can be easily made competent for genetic transformation. One of the reasons for interest in $B$. subtilis is that it is capable of undergoing physiological specialization to produce endospores under nutrient limiting conditions. This process of sporulation, which leads to spores of high chemical and physical resistance that can subsequently germinate in a range of favourable conditions, has been studied biochemically and genetically, and the positions on the genetic map of $B$. subtilis of a large range of genetic loci (spo and ger) involved in these processes have been determined (Henner \& Hoch, 1980).

There has been considerable progress recently in cloning these genes (Bonamy \& Szulmajster, 1982; Dubnau et al., 1981; Ferrari et al., 1981; Jenkinson \& Mandelstam, 1983; Mahler et al., 1984; Moir, 1983). Since selection for a $\mathrm{Spo}^{+}$or $\mathrm{Ger}^{+}$phenotype is not as easy as selection for prototrophy in an auxotrophic mutant, one approach adopted for cloning such genes has been to select hybrid plasmids or bacteriophages carrying the wild-type allele of a nearby auxotrophic marker and subsequently to screen for the presence or absence of the relevant spo or ger locus. The $c i t F$ gene cluster, recently redesignated $s d h$ for succinate dehydrogenase, and ger $E$ are one such closely linked set of loci, both of which are of considerable fundamental interest.

Membrane bound succinate dehydrogenase (SDH) is an important component of all aerobic cells. Its activity is modulated by several activators and inhibitors and SDH is a complex enzyme containing non-haem iron, acid-labile sulphur and covalently bound flavin adenine dinucleotide (FAD) (Hederstedt \& Rutberg, 1981). The composition, enzymology and basis of the membrane-binding properties of $B$. subtilis SDH have been extensively studied. However, little is known about the biosynthesis and genetics of this complex although the $s d h$ operon of Escherichia coli has recently been cloned and sequenced (Wood et al., 1984). In B. subtilis the SDH enzyme contains equimolar amounts of three subunits : a $M_{\mathrm{r}} 65000$ flavoprotein (FP), a $M_{\mathrm{r}}$

† Present address: Department of Microbiology, University of Leicester, Leicester LE1 7RH, UK.

Abbreviations: AEC, $S$-(2-aminoethyl)cysteine; SDH, succinate dehydrogenase. 
28000 iron protein (IP) and a $M_{\mathrm{r}} 19000$ cytochrome $b_{558}$ (Hederstedt et al., 1979; Hederstedt, 1980 ; Hederstedt $\&$ Rutberg, 1983). These are coded for by the $s d h B, C$ and $A$ loci, respectively (Hederstedt \& Rutberg, 1981; Hederstedt et al., 1982), which appear to compose an sdh operon (Magnusson et al., 1983) that is probably expressed constitutively. Sdh mutants accumulate organic acids (Carls \& Hanson, 1971) and are also defective in sporulation (Fortnagel \& Freese, 1968; Rutberg \& Hoch, 1970; Freese et al., 1978; Freese, 1981) probably due to inadequate production of ATP (Fortnagel \& Freese, 1968) and to the accumulation of inhibitory acidic intermediates (Freese et al., 1974).

The role of the product of the gerE locus in sporulation and germination is not fully understood. The spores of gerE36 mutants are smaller than those of wild-type strains, germinate slowly in a variety of germinants, are sensitive to lysozyme and have an incomplete spore coat (Moir, 1981). gerE36 mutants lack a protease which seems to be required for processing a number of polypeptides normally found in the spore coat (Jenkinson \& Lord, 1983). It is not clear, however, whether the protease is the product of gerE or whether its synthesis is regulated in some way by the gerE product.

Clearly, the cloning of both $s d h$ and ger $E$ loci would aid in the investigation of these different systems. In this paper we report the cloning of a genomic segment coding for the $s d h A, B$ and $C$ genes as well as ger $E$. The location of these genes relative to the restriction map is reported as well as a demonstration that the $\mathrm{GerE}^{+}$phenotype is dominant over $\mathrm{GerE}^{-}$.

\section{METHODS}

Bacterial strains and plasmids. These are listed in Tables 1 and 2, respectively.

Bacterial growth. Escherichia coli strains were grown in L broth or on L agar (Kahn et al., 1979) at $37^{\circ} \mathrm{C}$. Stock plates were stored at room temperature. Medium was supplemented with kanamycin $\left(50 \mu \mathrm{g} \mathrm{ml}^{-1}\right)$, tetracycline $\left(25 \mu \mathrm{g} \mathrm{ml}^{-1}\right)$, chloramphenicol $\left(5 \mu \mathrm{g} \mathrm{ml}^{-1}\right)$ or penicillin $\left(300 \mu \mathrm{g} \mathrm{ml}^{-1}\right.$ in L agar, $150 \mu \mathrm{g} \mathrm{ml}^{-1}$ in L broth) to select for appropriate antibiotic-resistance markers $\left(\mathrm{Km}^{\mathrm{R}}, \mathrm{Tc}^{\mathrm{R}}, \mathrm{Cm}^{\mathrm{R}}\right.$ and $\mathrm{Ap}^{\mathrm{R}}$, respectively).

Bacillus subtilis was grown at $37^{\circ} \mathrm{C}$ or $42^{\circ} \mathrm{C}$ using Difco Penassay Broth, Potato Glucose Yeast Extract (PGYE) agar (Dring \& Gould, 1971), Tryptose-blood Agar Base (Difco) solidified with 0.75\% (w/v) Difco agar and TY agar (Biswal et al., 1967) as rich nutrient media. Minimal Agar (Anagnostopoulos \& Spizizen, 1961) was supplemented with glucose $(0.5 \%)$ and amino acids $\left(50 \mu \mathrm{g} \mathrm{ml}^{-1}\right)$ where required. $\mathrm{CitF}^{+}$transformants were selected on minimal agar containing $0.5 \%(\mathrm{w} / \mathrm{v})$ sodium lactate (Rutberg \& Hoch, 1970). Nutrient agar containing bromocresol purple (Carls \& Hanson, 1971) was also used for screening for the $\mathrm{CitF}^{+}$phenotype. Chloramphenicol $\left(5 \mu \mathrm{g} \mathrm{ml}^{-1}\right)$ and $S$-(2-aminoethyl)cysteine (AEC, $100 \mu \mathrm{g} \mathrm{ml}^{-1}$ ) were used for the selection of resistance genes, $\mathrm{Cm}^{\mathrm{R}}$ and aec $A$, respectively. The spore germination phenotype (Ger) was scored by the tetrazolium overlay method (Trowsdale \& Smith, 1975; Lafferty \& Moir, 1977).

Transformation of bacteria. E. coli bacteria were made competent and transformed with plasmid DNA as described by Meyer et al. (1977) and modified by Thomas (1981). Transformation of $B$. subtilis was as described by Anagnostopoulos \& Spizizen (1961).

Extraction of DNA. For plasmid DNA a slightly modified version of the method of Birnboim \& Doly (1979) as described by Smith \& Thomas (1983) was used. B. subtilis chromosomal DNA was prepared according to Marmur (1961).

Restriction digestion and ligation. Restriction endonucleases and bacteriophage T4 DNA ligase were obtained from Bethesda Research Laboratories, P and S Biochemicals or NBL Enzymes and used under the conditions recommended by the suppliers.

Gel electrophoresis. Agarose gel electrophoresis $(0 \cdot 7-2 \cdot 0 \%$, w/v) was done as described by Kahn et al. (1979) with slight modifications (Thomas, 1983).

Dephosphorylation of vector DNA. Calf intestinal alkaline phosphatase (Boehringer Mannheim) was used to remove the terminal 5' phosphates of digested vector plasmid DNA (Chaconas \& van de Sande, 1980).

Size fractionation of chromosomal DNA. Chromosomal DNA of $B$. subtilis which had been partially digested with Sau $3 \mathrm{~A}$ was fractionated by velocity centrifugation through a sucrose density gradient to isolate fragments in the range $5-15 \mathrm{~kb}$ as described by Maniatis et al. (1978).

Characterization of spores. Spores were prepared on PGYE agar as previously described (Lafferty \& Moir, 1977). Lysozyme sensitivity was tested as described by Moir (1981) but using $100 \mu \mathrm{g}$ lysozyme $\mathrm{ml}^{-1}$. Germination was measured as described by Moir (1981) and Sammons et al. (1981).

Southern blotting. The BamHI to SalI $6.6 \mathrm{~kb}$ fragment from the B. subtilis DNA cloned in $\mathrm{pSH} 1047$ was isolated by bulk digestion of pSH1047 DNA with SalI and BamHI, agarose gel electrophoresis and electroelution. It was rendered radioactive by nick translation (Rigby et al., 1977) using [ $\left.\alpha{ }^{32} \mathrm{P}\right] \mathrm{dCTP}$. Plasmid $(1 \mu \mathrm{g})$ or chromosomal 
Table 1. Bacterial strains

Strain

Description

Reference or source*

E. coli $\mathrm{K} 12$

MVio

MV10Ch3/86

C600 AtrpE5

MV10 carrying hybrid $\lambda$ prophage $\mathrm{Ch} 3 / 86$ with $\operatorname{trf} A$ and $\operatorname{trf} B$ regions of plasmid $\mathrm{RK} 2$

HB101

$\mathrm{F}^{-}$hsdS20( $\left.\mathrm{r}_{\mathrm{B}}^{-} \mathrm{m}_{\mathrm{B}}^{-}\right)$recA13 ara-14 lacYl proA2 galK2 rpsL20(Sm $\left.{ }^{\mathrm{R}}\right) \quad x y l-5$ mtl-1 supE44 $\lambda^{-}$

ED8654

B. subtilis

PY79

4600

4700

4736

4709

4822

4985

4985.1

1604
supE supF hsd $R^{-} M^{+} S^{+}$met trpR

Prototroph

gerE36 trpC2 hisAl

cit $F 2$ trpC2

ilv $B 2$ gerE36

citF78 leuC2

citF83 leuC2

lys-1 aecA trpC2 sul

aec A trpC2 sul

$\operatorname{trp} C 2$
D. R. Helinski

Thomas et al. (1981)

D. R. Helinski

J. R. Guest; Murray et al. (1977)

Youngman et al. (1984)

Moir (1983)

L. Rutberg

Moir (1981)

L. Rutberg

L. Rutberg

W. Steinberg

Present study $\dagger$

Moir et al. (1979)

* D. R. Helinski, University of California, San Diego, USA; J. R. Guest, Department of Microbiology, University of Sheffield, UK ; L. Rutberg, Karolinska Institute, Stockholm, Sweden; W. Steinberg, University of Virginia Medical School, Charlottesville, Va., USA.

$\dagger$ B. subtilis strain 4985 was transformed with chromosomal DNA from PY79, selecting prototrophs for lysine on minimal plates.

Table 2. Plasmids

\begin{tabular}{|c|c|c|c|c|}
\hline Plasmid & \multicolumn{2}{|c|}{ Relevant properties } & Size $(k b)$ & Reference or source \\
\hline oBR322 & $A p^{R} T c^{R}$ & pMB1 replicon & $4 \cdot 362$ & Bolivar et al. (1977) \\
\hline pCT571 & $\mathrm{Km}^{\mathrm{R}} \mathrm{Tc}^{\mathrm{R}} \mathrm{Cm}^{\mathrm{R}}$ ori $V_{\mathrm{RK} 2}$ & pSC101 replicon & $9 \cdot 5$ & unpublished \\
\hline pSH 1047 & $\mathrm{Km}^{\mathrm{R}} \mathrm{Cm}^{\mathrm{R}}$ oriv $V_{\mathrm{RK} 2}$ & pSCl01 replicon & $17 \cdot 5$ & present study \\
\hline SH1047.1 & $\mathrm{Km}^{\mathrm{R}} \mathrm{Cm}^{\mathrm{R}}$ ori $V_{\mathrm{RK} 2}$ & pSCI01 replicon & $15 \cdot 95$ & present study \\
\hline SH 1047.3 & $\mathrm{Ap}^{\mathrm{R}} \mathrm{T}^{\mathrm{R}} \mathrm{Cm}^{\mathrm{R}}$ & pMB1 replicon & $8 \cdot 2$ & present study \\
\hline $\mathrm{oSH} 1047.4$ & $\mathrm{Km}^{\mathrm{R}} \mathrm{Cm}^{\mathrm{R}}$ ori $V_{\mathrm{RK} 2}$ & pSC 101 replicon & $15 \cdot 85$ & present study \\
\hline $\mathrm{oSH} 1047.5$ & $\mathrm{Km}^{\mathrm{R}} \mathrm{Cm}^{\mathrm{R}}$ ori $V_{\mathrm{RK} 2}$ & pSC101 replicon & $16 \cdot 2$ & present study \\
\hline $\mathrm{oSH} 1047.6$ & $\mathrm{Km}^{\mathrm{R}} \mathrm{Cm}^{\mathrm{R}}$ ori $V_{\mathrm{RK} 2}$ & pSC101 replicon & $16 \cdot 6$ & present study \\
\hline PSH 1047.7 & $\mathrm{Km}^{\mathrm{R}}$ ori $V_{\mathrm{RK} 2}$ & pSC101 replicon & 11.9 & present study \\
\hline${ }_{\mathrm{oSH}} 1047.10$ & $\mathrm{Km}^{\mathrm{R}} \mathrm{Cm}^{\mathrm{R}}$ ori $V_{\mathrm{RK}}$ ? & pSCI01 replicon & $12 \cdot 5$ & present study \\
\hline SH810 & $\mathrm{Km}^{\mathrm{R}} \mathrm{Cm}^{\mathrm{R}}$ ori $V_{\mathrm{RK} 2}$ & pSCl0I replicon & 20 (approx.) & unpublished \\
\hline
\end{tabular}

$(10 \mu \mathrm{g})$ DNA digested to completion with restriction endonucleases was separated by agarose gel electrophoresis, denatured, transferred to a sheet of Biodyne A (Pall Process Filtration, Portsmouth, UK) as described by Southern (1975) and then hybridized with the radioactive probe by the method recommended by the manufacturers of the Biodyne A nylon membranes.

\section{RESULTS}

\section{Isolation of hybrid plasmids carrying the cit $F$ region}

The vector used in this study is a pSC101-derived plasmid pCT571 (Fig. 1) whose construction will be described elsewhere (S. Hasnain \& C. M. Thomas, unpublished). It is $9.5 \mathrm{~kb}$ in size, has single restriction endonuclease sites for BamHI, EcoRI, SstII, XhoI, SmaI and SalI and carries genes conferring resistance to the antibiotics kanamycin, tetracycline and chloramphenicol in $E$. coli but only to chloramphenicol in B. subtilis. Plasmid pCT571 normally replicates in $E$. coli with a copy number of 6-8 per chromosome. However, it also contains a mutant vegetative replication origin from plasmid $\mathrm{RK} 2$, ori $V_{\mathrm{RK} 2}$, allowing it to replicate at 35-40 copies per chromosome when trf $A$ is supplied in trans (Thomas et al., 1984). Plasmid pCT571 cannot replicate in $B$. subtilis: it can only be used to transform $B$. subtilis to $\mathrm{Cm}^{\mathrm{R}}$ if it gains either a $B$. 


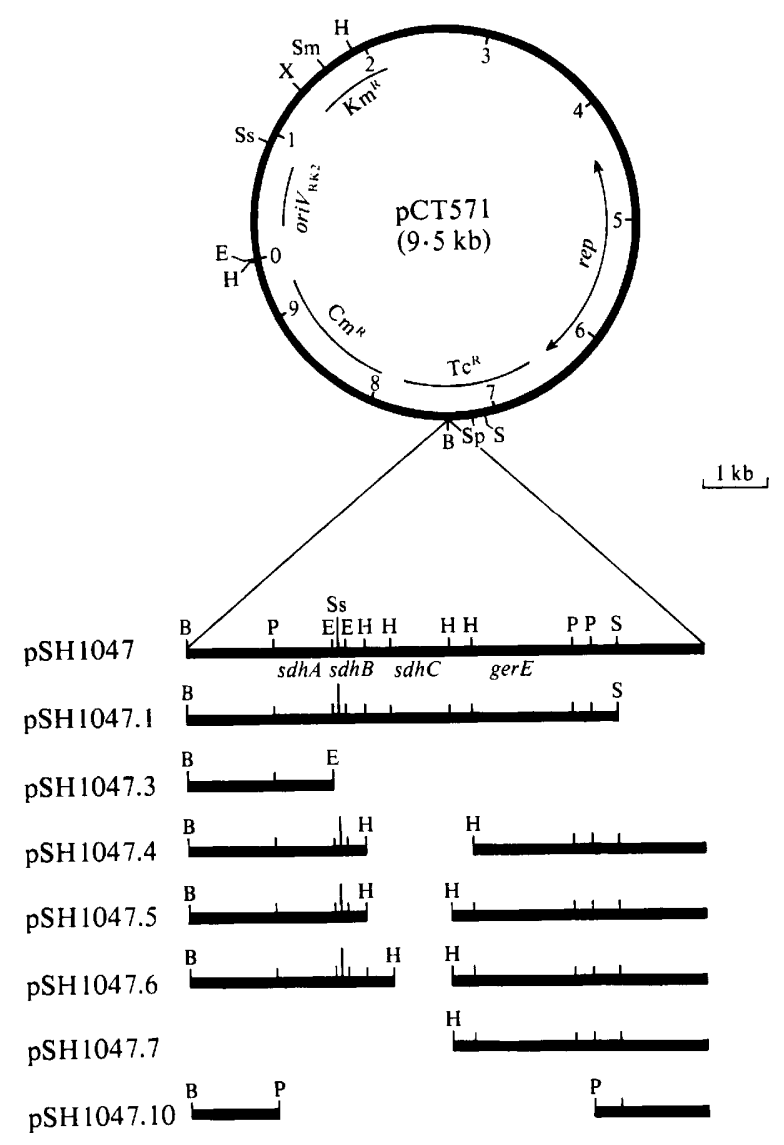

Fig. 1. Structure of the vector pCT571 and the physical and genetic map of B. subtilis genomic DNA present in pSH1047 and its derivatives. Restriction endonuclease cleavage sites are indicated as: B, E, H, S, Sm, Sp, Ss, X for BamHI, EcoRI, HindIII, SalI, SmaI, SphI, SstII and XhoI, respectively. Plasmid pSH1047.1 was made by deletion of the $1.55 \mathrm{~kb}$ Sall fragment; pSH1047.3 consists of the approximately $3.8 \mathrm{~kb}$ EcoRI fragment carrying the $\mathrm{Cm}^{\mathrm{R}}$ marker inserted into pBR322; pSH1047.4, pSH1047.5, pSH1047.6 and pSH1047.7 were created by partial digestion of pSH1047 DNA with $H$ indIII, ligation, transformation of $E$. coli and examination of the resulting plasmids for deletions of HindIII fragments; pSH1047.10 was made by deletion of the PstI fragments within the B. subtilis DNA. The scale bar refers to the inserts, not the circular plasmid map.

subtilis replicon or chromosomal DNA allowing it to integrate into the chromosome by homologous recombination.

A $B$. subtilis gene bank was created by ligating dephosphorylated BamHI-cleaved pCT571 to $5-15 \mathrm{~kb}$ chromosomal fragments produced by Sau3A partial digestion and fractionation on a sucrose gradient. After transformation of $E$. coli with the ligated DNA, $\mathrm{Km}^{\mathrm{R}}$ transformants were screened for insertional inactivation of the tetracycline resistance marker and plasmid DNA was extracted. Samples of the plasmid DNA preparations were pooled in batches of approximately 30 and introduced by transformation into $E$. coli strain MV10Ch3/86, where pCT571 derivatives will have a higher copy number, in order to obtain larger quantities of plasmid DNA with less RNA and chromosomal DNA contamination. This DNA was used to screen for the presence of wild-type cit $F$ DNA by transformation of $B$. subtilis strain 4822 (citF83) and selection on lactate plates. Chromosomal DNA of B. subtilis PY79 was used as a positive control and as an indicator of competence, while competent cells without DNA were used as a negative control. Out of 30 pools one showed positive results and on screening the individual plasmid DNAs from this pool two identical plasmids, with an approximately $8.0 \mathrm{~kb}$ 


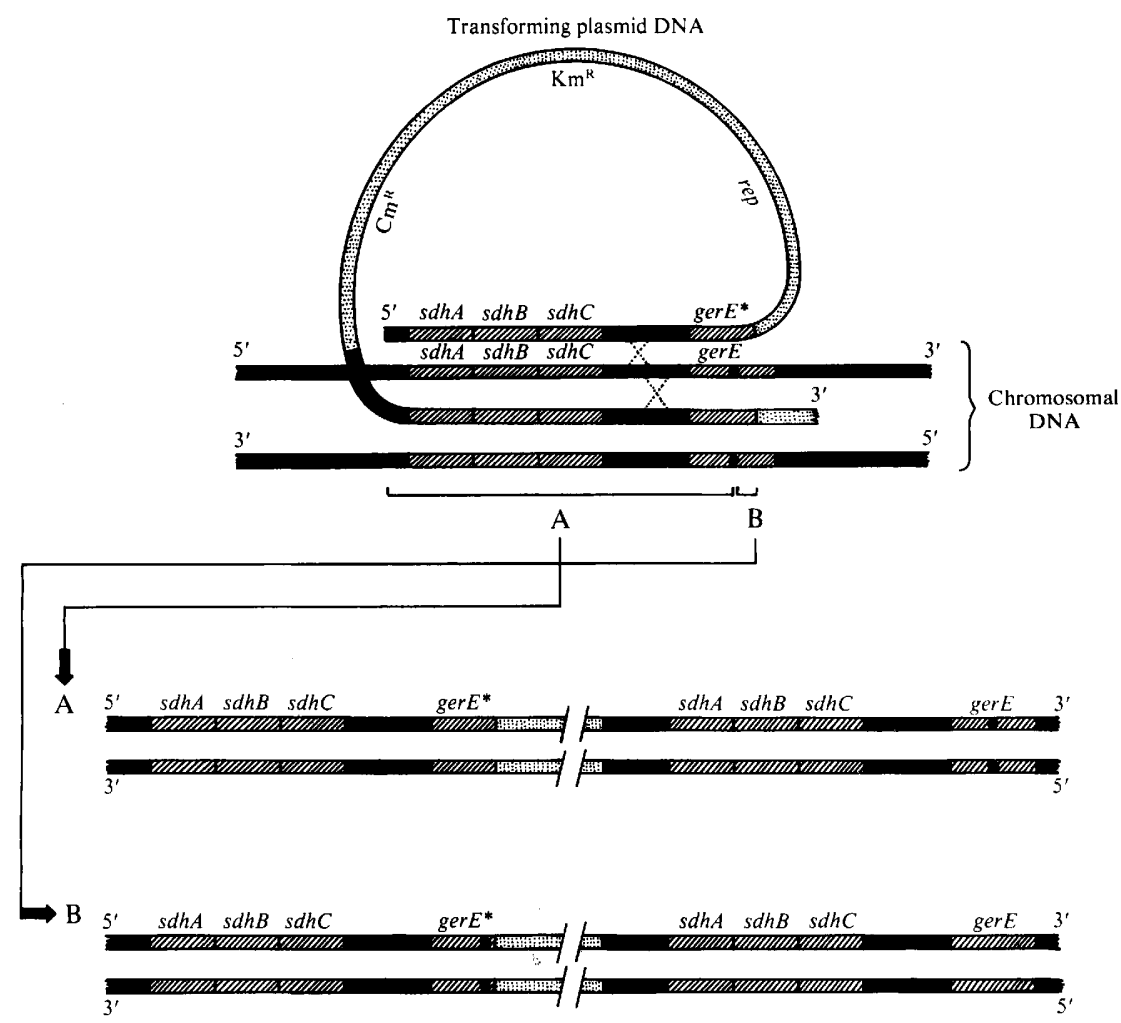

Fig. 2. Integration of $\mathrm{pSH} 1047$ into the chromosome of a $B$. subtilis gerE strain by homologous recombination. Integration could involve monomeric or multimeric single stranded plasmid DNA molecules. If only part ( $g e r E^{*}$ ) of the wild-type ger $E$ gene were present in pSH 1047 , then for integration to yield a functional ger $E$ gene, recombination (dashed cross) must take place in the interval $\mathbf{B}$, not in interval A. If the whole of the wild-type gerE gene were present in pSH1047 then integration would always yield one functional ger $E$ gene. The different types of DNA are shown as:, B. subtilis DNA;

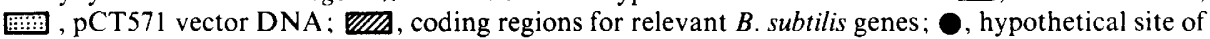
mutation in gerE gene.

insertion of $B$. subtilis DNA, were identified. These plasmids (pSH1041 and pSH1047) transformed the $c i t F 83$ strain (4822) to $\mathrm{CitF}^{+}$, indicating the presence of at least part of the $s d h C$ gene in which the citF83 mutation is located. Plasmid pSH 1047 was used to transform $B$. subtilis strain 4709 carrying the cit $F 78$ mutation, which lies in $s d h A$ at the other end of the $s d h$ cluster of genes. Many $\mathrm{CitF}^{+}$transformants were obtained, indicating that $\mathrm{pSH} 1047$ contains part, at least, of $s d h A$. If no deletion has occurred then $\mathrm{pSH} 1047$ should also contain $s d h B$ which lies between the $s d h A$ and $C$ loci.

\section{Plasmid pSH1047 carries the whole gerE locus}

Previous experiments (Moir, 1981; Hederstedt et al., 1982) have established that the order of loci in this region of the B. subtilis chromosome is $s d h A($ citF78) - sdhB (citF2) - sdhC (citF83)ger $E$ and that $g e r E$ is $90 \%$ linked by transformation to $s d h C$. It therefore seemed possible that gerE might be contained within the $8.0 \mathrm{~kb}$ chromosomal fragment. In order to determine if it was present, DNA of pSH1047 was used to transform a gerE strain (4736) to $\mathrm{Cm}^{\mathrm{R}}$ and 100 transformants were screened for $\mathrm{Ger}^{+}$by the tetrazolium overlay method. The results showed that $99 \%$ of the transformants were $\mathrm{Ger}^{+}$as indicated by the red colour of the colonies.

Integration of the $\mathrm{Cm}^{\mathrm{R}}$ marker must occur by homologous recombination between the $B$. subtilis DNA in pSH1047 and the resident genome, either via a simple Campbell-type integration or by a double cross-over with a single strand derived from a dimeric plasmid molecule (Fig. 2). In both cases the result is a duplication of the genomic segment present in 
pSH1047. A cross-over can occur at a range of sites so that if only part of the gerE gene was present in pSH1047 then only a proportion of the $\mathrm{Cm}^{\mathrm{R}}$ transformants would be expected to restore $g e r E^{+}$, while if the whole of $g e r E^{+}$is present then all $\mathrm{Cm}^{\mathrm{R}}$ transformants should have acquired an extra wild-type copy of gerE. Since we found that virtually all $\mathrm{Cm}^{\mathrm{R}}$ transformants were $\mathrm{Ger}^{+}$it was concluded that the whole of gerE is likely to be present in pSH1047.

In order to confirm that the colonies identified by the tetrazolium overlay method represent transformants that have been fully converted to $\mathrm{Ger}^{+}, \mathrm{Cm}^{\mathrm{R}}$ transformants obtained with pSH1047 were used to prepare spores. These were found to be fully resistant to lysozyme, of wild-type size rather than small as found for gerE spores, and able to germinate normally in $10 \mathrm{~mm}$-alanine (data not shown). $\mathrm{Cm}^{\mathrm{R}}$ transformants obtained with a different hybrid plasmid, pSH810, which was picked at random, were found to retain $g e r E$ characteristics, indicating that mere integration of pCT571 into the $B$. subtilis genome does not alter sporulation and spore characteristics. Since the results show that the $\mathrm{Cm}^{\mathrm{R}}$ transformants of the ger $E$ strain, which should have become partial diploids for the gerE locus and therefore contain both mutant and wild-type gerE loci, are fully $\mathrm{Ger}^{+}$phenotypically, it is clear that the GerE ${ }^{+}$phenotype is fully dominant over GerE-'.

\section{Physical characterization of $B$. subtilis DNA in pSH1047}

In order to generate a restriction map of the $B$. subtilis DNA in pSH1047 the following endonucleases were used separately and in combination: EcoRI, SalI, XhoI, HindIII, BamHI, SstII, PstI, BglII. There were three PstI, two EcoRI, one SstII, four HindIII and one SalI sites in the approximately $8.0 \mathrm{~kb} \mathrm{~B}$. subtilis segment. Interestingly; the Sau3A site at one end of the insert restored the BamHI site near the EcoRI and HindIII sites of the vector.

To check that the cloned segment in pSH1047 was really B. subtilis DNA and to determine whether any significant deletions had occurred in the cloning process, Southern blotting was used to examine chromosomal DNA of $B$. subtilis PY79, from which the fragments came originally, using the BamHI to $\mathrm{Sal}$ I fragment of $\mathrm{pSH} 1047$ as a radioactivvely labelled probe. Chromosomal DNA digested with EcoRI, HindIII, PstI and EcoRI plus SalI together was examined in this way, comparing the radioactive bands produced with those produced by the same digestions of pSH1047 DNA (data not shown). First, the results confirmed that the cloned DNA is homologous to PY79 DNA, ruling out the possibility that is is a totally spurious segment of DNA. Second, while we were unsuccessful in confirming the presence in the chromosomal digests of hybridizing bands corresponding to the small EcoRI and HindIII bands of pSH1047, hybridization did occur to both a PstI band and an EcoRI to $S a l$ band of exactly the same sizes as the ones covering the major area coding for $s d h A, B$ and $C$ and ger $E$ in pSH1047 (Fig. 1). We therefore concluded that no significant deletion has occurred in this cloned segment and that it probably represents a natural segment of the $B$. subtilis genome.

\section{Deletion analysis of genetic loci}

We used deletion derivatives of $\mathrm{pSH} 1047$ to locate on the $B$. subtilis genomic segment the regions coding for the subunits of the SDH complex, as defined by previously isolated mutants, and gerE. A series of seven deletion derivatives, as shown in Fig. 1, were utilized. Plasmids pSH1047.1, pSH1047.4, pSH1047.5, pSH1047.6 and pSH1047.10 retain the $\mathrm{Km}^{\mathrm{R}}$ and $\mathrm{Cm}^{\mathrm{R}}$ markers of pSH1047, whereas pSH1047.7 has lost the $\mathrm{Cm}^{\mathrm{R}}$. All these plasmids represent the results of digestion, partial or complete, with restriction endonucleases SalI, HindIII or PstI, ligation and transformation of $E$. coli MV10 selecting the appropriate antibiotic resistance markers. Plasmid pSH1047.3 was made by inserting the EcoRI fragment containing the $\mathrm{Cm}^{\mathrm{R}}$ marker of pSH1047 into pBR322 at the EcoRI site and consequently it confers $\mathrm{Ap}^{\mathrm{R}}$, $\mathrm{Tc}^{\mathrm{R}}$ and $\mathrm{Cm}^{\mathrm{R}}$. In order to determine the positions of the three $s d h$ loci on the inserted fragment, competent $c i t F 78(s d h A), c i t F 2(s d h B)$ and $c i t F 83(s d h C)$ mutant strains were transformed with DNA of pSH1047 and its derivatives. Mutants defective in tricarboxylic acid cycle enzymes accumulate organic acids and on medium containing the $\mathrm{pH}$ indicator bromocresol purple they form yellow colonies while wild-type colonies are blue (Carls \& Hanson, 1971). We selected 
Table 3. Results of testing pSH1047 and its derivatives for wild-type sdh genes

B. subtilis strains 4709,4700 and 4822 , carrying cit $F$ mutations, were transformed with plasmid DNA. Selection of $\mathrm{CitF}^{+}$transformants on lactate plates was carried outat least twice,yielding qualitatively similar results. One set of results are shown; they represent the number of transformants per $\mu \mathrm{g}$ plasmid DNA. For screening the $\mathrm{CitF}$ phenotype of $\mathrm{Cm}^{\mathrm{R}}$ transformants on bromocresol purple plates the cumulated results from several experiments are shown, the total number of $\mathrm{Cm}^{\mathrm{R}}$ transformants being low.

$s d h$ locus (citF mutation in strain used for test):

\begin{tabular}{|c|c|c|c|c|c|}
\hline \multirow[b]{2}{*}{ Plasmid } & \multicolumn{2}{|c|}{$s d h A($ citF78) } & \multirow{2}{*}{$\begin{array}{l}\text { sdhB }(\operatorname{cit} F 2) \\
\text { No. of } \mathrm{CitF}^{+} / \\
\text {no. of } \mathrm{Cm}^{\mathrm{R}} \\
\text { tested }\end{array}$} & \multicolumn{2}{|c|}{$s d h C$ (citF83) } \\
\hline & $\begin{array}{c}\text { No. of } \mathrm{CitF}^{+} \\
\text {transformants } \\
\text { on lactate plates }\end{array}$ & $\begin{array}{c}\text { No. of } \mathrm{CitF}^{+} / \\
\text {no. of } \mathrm{Cm}^{\mathrm{R}} \\
\text { tested }\end{array}$ & & $\begin{array}{l}\text { No. of } \mathrm{CitF}^{+} \\
\text {transformants on } \\
\text { lactate plates }\end{array}$ & $\begin{array}{l}\text { No. of } \mathrm{CitF}^{+} / \\
\text {no. of } \mathrm{Cm}^{\mathrm{R}} \\
\text { tested }\end{array}$ \\
\hline pSH 1047 & 650 & $0 / 0$ & $23 / 23$ & 400 & $11 / 12$ \\
\hline pSH 1047.1 & 600 & $45 / 46$ & $9 / 9$ & 200 & $1 / 12$ \\
\hline pSH 1047.3 & 100 & $13 / 13$ & $1 / 63$ & 0 & $0 / 13$ \\
\hline pSH 1047.4 & 80 & $2 / 2$ & $4 / 4$ & 0 & $0 / 0$ \\
\hline $\mathrm{pSH} 1047.5$ & 22 & $3 / 3$ & $26 / 26$ & 0 & $0 / 0$ \\
\hline pSH 1047.6 & 100 & $0 / 0$ & $26 / 26$ & 0 & $0 / 0$ \\
\hline pSH1047.7 & 0 & ND & ND & 0 & ND \\
\hline $\mathrm{pSH} 1047.10$ & 0 & $0 / 1$ & $0 / 1$ & 0 & $0 / 0$ \\
\hline
\end{tabular}

ND, Not determined due to lack of the $\mathrm{Cm}^{\mathrm{R}}$ marker in pSH1047.7.

transformants of citF strains both on such plates supplemented with chloramphenicol and on lactate plates (Table 3).

With the cit $F 78$ mutant strain it was found that all pSH1047 derivatives which gave $\mathrm{CitF}^{+}$ transformants on lactate plates contained the BamHI to EcoRI fragment adjacent to the $\mathrm{Cm}^{\mathrm{R}}$ marker. Of the two plasmids which did not yield such $\mathrm{CitF}^{+}$transformants, pSH1047.10 contains the BamHI to Pst I subsegment of this fragment (Fig. 1), suggesting that the wild-type allele of citF78 lies in the remaining PstI to EcoRI fragment. The results of selecting $\mathrm{Cm}^{\mathrm{R}}$ transformants on bromocresol purple plates, which allowed $\mathrm{CitF}^{+}$to $\mathrm{CitF}^{-}$to be scored, were not thoroughly convincing due to the generally low numbers of transformants. However, as argued above for screening for the gerE gene, since all $\mathrm{Cm}^{\mathrm{R}}$ transformants with plasmid pSH1047.3 were $\mathrm{CitF}^{+}$it appears likely that the $s d h A$ gene lies entirely to the left (in Fig. 1) of the EcoRI site and may or may not extend left of the $P_{s t} \mathrm{I}$ site. The single yellow $\left(\mathrm{CitF}^{-}\right) \mathrm{Cm}^{\mathrm{R}}$ transformant obtained with pSH1047.10 confirms the location of at least part of $s d h A$ right of the Pst I site. The disappointingly low number of $\mathrm{Cm}^{\mathrm{R}}$ transformants obtained is a reflection of the poor competence of citF strains. However, these results are not the sole basis of our conclusions and are reported simply for completeness.

With the citF83 mutant strain the ability of pSH1047 to give $\mathrm{CitF}^{+}$transformants was abolished by deletion of the $0.9 \mathrm{~kb}$ HindIII fragment (pSH1047.6). Thus, the only derivative that gave $\mathrm{CitF}^{+}$transformants was $\mathrm{pSH} 1047.1$, which retained this DNA fragment; the other plasmids lacked this fragment and none of them gave $\mathrm{CitF}^{+}$transformants. Again, the low number of $\mathrm{Cm}^{\mathrm{R}}$ transformants on bromocresol purple plates meant that this test was inconclusive. However, the results using lactate plates do show clearly that the $s d h C$ gene must lie at least partly within the $0.9 \mathrm{~kb}$ HindIII fragment.

With the citF2 mutant strain we were unsuccessful in getting transformation to $\mathrm{CitF}^{+}$on lactate plates. However, the number of $\mathrm{Cm}^{\mathrm{R}}$ transformants was significant for most of the plasmids and the results show that all $\mathrm{Cm}^{\mathrm{R}}$ transformants obtained with plasmids carrying DNA left of the leftmost $H$ indIII site (in Fig. 1) are $\mathrm{CitF}^{+}$while with pSH1047.3, carrying DNA left of the leftmost $E c o R I$ site, only one out of $63 \mathrm{Cm}^{\mathrm{R}}$ transformants was $\mathrm{CitF}^{+}$. This suggests that while pSH1047.3 may have the wild-type sequence which is mutant in citF2 the whole of the cistron cannot be present. The $s d h B$ gene may therefore flank the leftmost EcoRI site.

This order of $s d h$ loci is consistent with the results of classical genetic mapping. It appears that they are encoded mainly, if not entirely, by the approximately $3.0 \mathrm{~kb}$ segment, from the leftmost PstI site to the rightmost HindIII site. 
Table 4. Results of testing pSH1047 and its derivatives for wild-type gerE and aecA genes

$B$. subtilis strains with ger $E$ and aec $A$ mutations were transformed to $\mathrm{Cm}^{\mathrm{R}}$ with plasmid DNA and then tested for $\mathrm{Ger}^{+}$by the tetrazolium overlay method or for AEC sensitivity $\left(\mathrm{Aec}^{+}\right)$as described in Methods.

\begin{tabular}{|c|c|c|}
\hline Plasmid & $\begin{array}{c}\text { gerE } \\
\text { No. of } \mathrm{Ger}^{+} / \\
\text {no. of } \mathrm{Cm}^{\mathrm{R}} \text { tested }\end{array}$ & $\begin{array}{c}\operatorname{aec} A \\
\text { No. of } \mathrm{Aec}^{+} / \\
\text {no. of } \mathrm{Cm}^{\mathrm{R}} \text { tested }\end{array}$ \\
\hline pSH1047 & $198 / 200$ & $0 / 24$ \\
\hline pSH 1047.1 & $50 / 50$ & $0 / 24$ \\
\hline pSH1047.3 & $0 / 50$ & $0 / 24$ \\
\hline pSH1047.4 & $50 / 50$ & $0 / 10$ \\
\hline pSH 1047.5 & $49 / 50$ & $0 / 1$ \\
\hline pSH1047.6 & $50 / 50$ & $0 / 5$ \\
\hline pSH 1047.7 & $36 / 250^{*}$ & ND \\
\hline pSH 1047.10 & $0 / 50$ & $0 / 12$ \\
\hline
\end{tabular}

These pSH1047 derivatives were also tested for retention of gerE (Table 4). For all plasmids except $\mathrm{pSH} 1047.7 \mathrm{Cm}^{\mathrm{R}}$ transformants were selected and tested for the $\mathrm{Ger}^{+}$phenotype. Plasmid pSH1047.7 was tested by a congression experiment as follows. B. subtilis strain 4600 (gerE36 $\operatorname{trpC2}$ his $A 1$ ) was transformed with gerE36 trp ${ }^{+}$DNA in the presence of pSH1047.7 DNA and transformants for the unlinked marker $\operatorname{trpC2}$ were selected. All $\mathrm{Trp}^{+}$transformants will have a high probability of having been transformed with pSH1047.7 DNA due to its being present in close to saturating amounts. Since pSH1047.7 is the only potential source of ger $E^{+}$DNA then only if it is $g e r E^{+}$should we find a significant proportion of $\mathrm{Trp}^{+} \mathrm{Ger}^{+}$double transformants. The results (Table 4) show that the only segment common to all plasmids which gave $\mathrm{Ger}^{+}$ transformants is the HindIII to SalI fragment of $2.25 \mathrm{~kb}$ (Fig. 1). Since all $\mathrm{Cm}^{\mathrm{R}}$ transformants obtained with pSH1047.1 and pSH1047.4 are $\mathrm{Ger}^{+}$it appears that both these plasmids must contain a complete gene. Further deletion analysis and subcloning will be necessary to establish the exact location of the gerE locus.

The aec $A$ gene, mutations in which give resistance to the lysine analogue AEC maps near to the $s d h$ gene cluster but on the side distal to gerE (Magnusson et al., 1983). B. subtilis strain 4985.1 ( $\operatorname{trpC2}$ aecA $\mathrm{sul}$ ) was transformed with DNA of pSH1047 as well as DNA of all the $\mathrm{Cm}^{\mathrm{R}}$ deletion derivatives. $\mathrm{Cm}^{\mathrm{R}}$ transformants were obtained and then tested for their Aec phenotype. All the transformants remained resistant to AEC (Table 4), indicating either that pSH1047 does not carry the whole of aec $A$ gene or that AEC resistance is dominant to AEC sensitivity.

\section{DISCUSSION}

High copy number vectors can be useful in producing large amounts of both the DNA and the products of cloned genes. However, they may accentuate problems of genetic instability if the gene being sought is itself, or is closely linked to segments which are, deleterious to the bacterial host being used, or which promote recombination. Since attempts to clone some genes of $B$. subtilis have been unsuccessful we have created a novel gene bank based on a low copy number vector, pCT571, which utilizes the pSC101 replicon (6-8 copies per chromosome equivalent) in E. coli. This vector cannot replicate in $B$. subtilis but does carry a $\mathrm{Cm}^{\mathrm{R}}$ marker which is expressed in B. subtilis. Transformation of $B$. subtilis strains to $\mathrm{Cm}^{\mathrm{R}}$ is dependent on insertion of $B$. subtilis chromosomal DNA into the plasmid thus allowing homologous recombination to occur. The presence of specific genetic markers can be tested either by directly transforming for an easily selected marker or by first selecting $\mathrm{Cm}^{\mathrm{R}}$ transformants and then screening for the acquisition of a chromosomal marker. Either method depends on efficient transformation of competent bacteria - particularly if pooled hybrid plasmids are being screened. Plasmid pCT571 carries a 
mutant vegetative replication origin of plasmid RK2 so that on introduction into an $E$. coli strain that provides the $\operatorname{trf} A$ gene, which is essential for replication from $o r i V_{\mathrm{RK} 2}$, the copy number of pCT571 rises to 35-40 per chromosome equivalent. Over short periods at least there seem to be no problems either with host growth or with plasmid structural stability in increasing the copy number of the hybrid plasmids described in this paper. We found that the higher copy number obtained in this way allowed us to isolate, by standard rapid techniques, DNA which gave better transformation frequencies in $B$. subtilis than those obtained for DNA isolated from the low copy number strains. The reason for this may be the more favourable ratio of plasmid DNA to contaminating chromosomal DNA and RNA which may competitively inhibit transformation. However, since the stimulation of transformation to $\mathrm{Cm}^{\mathrm{R}}$, which depends on the $\mathrm{Cm}^{\mathrm{R}}$ being either in a circular plasmid or flanked by direct repeats of chromosomal DNA, is greater than that for directly selectable chromosomal markers, whose integration depends only on linear homology with chromosomal DNA, it seems likely that increased copy number is having a major part of its effect by increasing the amount of dimeric plasmid molecules present since these are likely to be important in integration of $\mathrm{Cm}^{\mathrm{R}}$ into the chromosome (Canosi et al., 1978) (see Fig. 2). This explanation is consistent with the observation that DNA of pSH1041 and $\mathrm{pSH} 1047$, when isolated from a strain in which only the pSC101 replicon is functional, gives no visible dimeric form while if isolated from $\mathrm{MV} 10 \mathrm{Ch} 3 / 86$, where the higher copy number mutant RK2 replicon is activated, it gives clearly visible quantities of dimeric and trimeric forms (S. Hasnain, unpublished observation). The rather poor transformation frequencies for $\mathrm{Cm}^{\mathrm{R}}$ obtained in this present study probably reflect a combination of this extra constraint coupled with the difficulties of making cit $F$ mutant strains competent for transformation. Further analysis of the gene bank used here, including the examination of the effect of copy number on recovery and stability of different chromosomal loci, will be reported elsewhere (S. Hasnain \& C. M. Thomas, unpublished).

The genomic segment in pSH1047 appears to be a true representation of the chromosomal genes rather than being a deleted or rearranged version. The arrangement of $s d h$ loci and ger $E$ are consistent with previously reported genetic maps and the relative distances, as far as we can judge, are in agreement with recombination frequencies between loci reported previously (Magnusson et al., 1983; Moir, 1981). The results described here also suggest that at least part of the aec $A$ locus is absent from pSH1047. Interestingly, in screening for this marker we observed that we needed $100 \mu \mathrm{g} \mathrm{AEC} \mathrm{ml} l^{-1}$ to inhibit growth of our wild-type in contrast to $50 \mu \mathrm{g} \mathrm{ml}^{-1}$ reported previously (Mattioli et al., 1979) and that in the presence of $50 \mu \mathrm{g}$ lysine $\mathrm{ml}^{-1}$ the wildtype is resistant to even $400 \mu \mathrm{g} \mathrm{AEC} \mathrm{ml}{ }^{-1}$. Thus the exact relationship between lysine and its analogue may be strain dependent.

Possession of this clone provides the opportunity to investigate the $s d h$ and gerE loci in more detail, both at the level of the primary sequence of genes and with regard to the nature of their gene expression signals. It will be interesting to analyse the operon structure of the $s d h$ genes and to determine whether gerE falls into the category of genes whose expression is switched on during sporulation by the alterations in RNA polymerase specificity due to sigma factor changes. Such work is currently being pursued.

We thank all those who provided bacterial strains and plasmids used in this work: D. R. Helinski, J. R. Guest, L. Rutberg and W. Steinberg. In addition we thank H. Howell, C. Price and J. Yeomans for technical assistance and E. Badger for help in preparation of the manuscript. S. H. is the recipient of a Pakistan Government Scholarship; R.S. was a Research Associate on SERC Project no. GR/B95936 awarded to D. A. Smith and A. Moir; I.R. was funded by an SERC Quota Award.

\section{REFERENCES}

ANAgnostopoulos, C. \& SPIZIZEN, J. (1961). Requirements for transformation in Bacillus subtilis. Journal of Bacteriology 81, 741-746.
BIRnBoim, H. C. \& Doly, J. (1979). A rapid alkaline extraction procedure for screening recombinant plasmid DNA. Nucleic Acids Research 7, 1513-1523. 
Biswal, N., Kleinschmidt, A. K., Spatz, H. C. \& Trautner, T. A. (1967). Physical properties of the DNA of bacteriophage SP50. Molecular and General Genetics 100, 39-55.

Bolivar, F., Rodriguez, R. L., Greene, P. J., Betlach, M. V., Heynecker, H. L., Boyer, H. W., Crosa, J. H. \& FalKow, S. (1977). Construction and characterization of new cloning vehicles. II. A multipurpose cloning system. Gene 2, 95-113.

Bonamy, C. \& Szulmajster, J. (1982). Cloning and expression of Bacillus subtilis spore genes. Molecular and General Genetics 188, 202-210.

Canosi, U., Morelli, G. \& Trautner, T. A. (1978). The relationship between molecular structure and transformation efficiency of some $S$. aureus plasmids isolated from B. subtilis. Molecular and General Genetics 166, 259-267.

CARLS, R. A. \& Hanson, R. S. (1971). Isolation and characterisation of tricarboxylic acid cycle mutants of Bacillus subtilis. Journal of Bacteriology 106, 848855.

Chaconas, G. \& van de Sande, J. H. (1980). 5'-32P labelling of RNA and DNA restriction fragments. Methods in Enzymology 65, 75-85.

Dring, G. J. \& Gould, G. W. (1971). Movement of potassium during L-alanine-initiated germination of Bacillus subtilis spores. In Spore Research 1971, pp. 133-142. Edited by A. N. Barker, G. W. Gould \& J. Wolf. London: Academic Press.

Dubnau, E., Ramakrishna, N., Cabane, K. \& Smith, I. (1981). Cloning of a sporulation gene in Bacillus subtilis. In Sporulation and Germination, pp. 104-108. Edited by H. S. Levinson, A. L. Sonenshein \& D. J. Tipper. Washington, DC: American Society for Microbiology.

Ferrari, E., Henner, D. J. \& Hoch, J. A. (1981). Isolation of Bacillus subtilis genes from a Charon 4A library. Journal of Bacteriology 146, 430-432.

FortnaGel, P. \& FreEse, E. (1968). Analysis of sporulation mutants. II. Mutants blocked in the citric acid cycle. Journal of Bacteriology 95, 14311438.

FreESE, E. (1981). Initiation of bacterial sporulation. In Sporulation and Germination, pp. 1-12. Edited by H. S. Levinson, A. L. Sonenshein \& D. J. Tipper. Washington, DC: American Society for Microbiology.

Freese, E., Ichikawa, T., OH, Y. K., Freese, E. B. \& Prasad, C. (1974). Deficiencies or excesses of metabolites interfering with differentiation. Proceedings of the National Academy of Sciences of the United States of America 71, 4188-4193.

Freese, E., Heinze, J., Mitani, T. \& Freese, E. B. (1978). Limitation of nucleotides induces sporulation. In Spores VII, pp. 277-285. Edited by G. Chambliss \& J. C. Vary. Washington DC: American Society for Microbiology.

HederstedT, L. (1980). Cytochrome $b$ reducible by succinate in an isolated succinate dehydrogenasecytochrome $b$ complex from Bacillus subtilis membranes. Journal of Bacteriology 144, 933-940.

Hederstedt, L. \& RUTBERG, L. (1980). Biosynthesis and membrane binding of succinate dehydrogenase in Bacillus subtilis. Journal of Bacteriology 144, 941951.

Hederstedt, L. \& Rutberg, L. (1981). Succinate dehydrogenase - a comparative review. Microbiological Reviews 45, 542-555.

HEDERSTEDT, L. \& RuTberG, L. (1983). Orientation of succinate dehydrogenase and cytochrome $b_{558}$ in the Bacillus subtilis cytoplasmic membrane. Journal of Bacteriology 153, 57-65.

Hederstedt, L., Holmgren, E. \& Rutberg, L. (1979). Characterization of succinate dehydrogenase complex solubilized from the cytoplasmic membrane of Bacillus subtilis with the nonionic detergent Triton X-100. Journal of Bacteriology 138, 370-376.

Hederstedt, L., Magnusson, K. \& Rutberg, L. (1982). Reconstitution of succinate dehydrogenase in Bacillus subtilis by protoplast fusion. Journal of Bacteriology 152, 157-165.

HenNeR, D. J. \& Hoch, J. A. (1980). The Bacillus subtilis chromosome. Microbiological Reviews 44, 5782.

Jenkinson, H. F. \& LoRD, H. (1983). Protease deficiency and its association with defects in spore coat structure, germination and resistance properties in a mutant of Bacillus subtilis. Journal of General Microbiology 129, 2727-2737.

Jenkinson, H. F. \& Mandelstam, J. (1983). Cloning of the Bacillus subtilis lys 3 and spoIIIB genes in phage $\phi 105$. Journal of General Microbiology 129, 22292240.

Kahn, M., Kolter, R., Thomas, C., Figurski, D., Meyer, R., Remaut, E. \& Helinski, D. R. (1979). Plasmid cloning vehicles derived from plasmids ColE1, F, R6K and RK2. Methods in Enzymology 68, 268-280.

LAFFERTY, E. \& MoIR, A. (1977). Further studies on conditional germination mutants of Bacillus subtilis 168. In Spore Research 1976, pp. 87-105. Edited by A. N. Barker, J. Wolf, D. J. Ellar, G. H. Dring \& G. W. Gould. London: Academic Press.

Magnusson, K., Rutberg, B., Hederstedt, L. \& RUTBERG, L. (1983). Characterization of a pleiotropic succinate dehydrogenase-negative mutant of Bacillus subtilis. Journal of General Microbiology 129, 917-922.

MaHLER, I., Warburg, R., Tipper, D. J. \& HalvorSON, H. O. (1984). Cloning of an unstable spoIIAtyrA fragment from Bacillus subtilis. Journal of General Microbiology 130, 411-421.

Maniatis, T., Hardison, R. C., Lacy, E., Lauer, J., O'Connel, C., Quon, D., Sim, D. K. \& EfstratiaDIS, A. (1978). The isolation of structural genes from libraries of eucaryotic DNA. Cell 15, 685-701.

MARMUR, J. (1961). A procedure for the isolation of deoxyribonucleic acid from microorganisms. Journal of Molecular Biology 3, 208-218.

Mattioli, R., Bazzicalupo, M., Federici, G., GalLORI, E. \& Polsinelli, M. (1979). Characterization of mutants of Bacillus subtilis resistant to $S$-(2-aminoethyl)cysteine. Journal of General Microbiology 114, 223-225.

Meyer, R., Figurski, D. \& Helinski, D. R. (1977). Physical and genetic studies with restriction endonucleases on the broad host range plasmid RK2. Molecular and General Genetics 152, 129-135.

MoIR, A. (1981). Germination properties of a spore coat-defective mutant of Bacillus subtilis. Journal of Bacteriology 146, 1106-1116.

MoIR, A. (1983). The isolation of $\lambda$ transducing phage 
carrying the cit $G$ and ger $A$ genes of Bacillus subtilis. Journal of General Microbiology 129, 303-310.

Molr, A., Lafferty, E. \& SMith, D. A. (1979). Genetic analysis of spore germination mutants of Bacillus subtilis 168: the correlation of phenotype with map location. Journal of General Microbiology 111, 165-168.

Murray, N. E., Brammar, W. J. \& Murray, K. (1977). Lambdoid phage that simplify the recovery of in vitro recombinants. Molecular and General Genetics 150, 53-61.

Rigby, P. W. J., Dieckman, M., Rhodes, C. \& Berg, P. (1977). Labelling deoxyribonucleic acid to high specific activity in vitro by nick translation with DNA polymerase I. Journal of Molecular Biology 113, 237-251.

Rutberg, B. \& Hoch, J. A. (1970). Citric acid cycle: gene-enzyme relationships in Bacillus subtilis. Journal of Bacteriology 104, 826-833.

Sammons, R. L., MoIr, A. \& Smith, D. A. (1981). Isolation and properties of spore germination mutants of Bacillus subtilis 168 deficient in the initiation of germination. Journal of General Microbiology 124, 229-241.

Smith, C. A. \& Thomas, C. M. (1983). Deletion mapping of kil and kor functions in the $\operatorname{trf} A$ and $\operatorname{tr} f B$ regions of broad host range plasmid RK2. Molecular and General Genetics 190, 245-254.

SOUTHERN, E. (1975). Detection of specific sequences among DNA fragments separated by gel electrophoresis. Journal of Molecular Biology 98, 503-517.
Thomas, C. M. (1981). Complementation analysis of replication and maintenance functions of broad host range plasmids RK2 and RP1. Plasmid 5, 277-291.

ThomAs, C. M. (1983). Instability of a high copy number mini-plasmid derived from broad host range IncP plasmid RK2. Plasmid 10, 184-195.

Thomas, C. M., Stalker, D. M. \& Helinski, D. R. (1981). Replication and incompatibility properties of segments of the origin region of replication of broad host range plasmid RK2. Molecular and General Genetics 181, 1-7.

Thomas, C. M., Cross, M. A., Hussain, A. A. K. \& SmITH, C. A. (1984). Analysis of copy number control elements in the region of the vegetative replication origin of the broad host range plasmid RK2. EMBO Journal 3, 57-63.

Trowsdale, J. \& Smith, D. A. (1975). Isolation, characterization and mapping of Bacillus subtilis 168 germination mutants. Journal of Bacteriology 123, 83-95.

Wood, D., Darlison, M. G., Wilde, R. J. \& Guest, J. R. (1984). Nucleotide sequence encoding the flavoprotein and hydrophobic subunits of the succinate dehydrogenase of Escherichia coli. Biochemical Journal 222, 519-534.

Youngman, P., Perkins, J. B. \& Losick, R. (1984). Construction of a cloning site near one end of Tn917 into which foreign DNA may be inserted without affecting transposition in Bacillus subtilis or expression of the transposon borne erm gene. Plasmid 12, 19. 